AperTO - Archivio Istituzionale Open Access dell'Università di Torino

\title{
Cities are not products
}

\section{This is the author's manuscript}

Original Citation:

Availability:

This version is available http://hdl.handle.net/2318/1723828

since 2020-01-17T15:21:14Z

Published version:

DOI:10.1111/tesg.12385

Terms of use:

Open Access

Anyone can freely access the full text of works made available as "Open Access". Works made available under a Creative Commons license can be used according to the terms and conditions of said license. Use of all other works requires consent of the right holder (author or publisher) if not exempted from copyright protection by the applicable law. 


\title{
CITIES ARE NOT PRODUCTS
}

\author{
Alberto Vanolo
}

Manuscript; final version published as:

Vanolo A. (2020), "Cities are not products", Tijdschrift voor Economische en Sociale Geografie, v. 111, n. 1, pp. 10-17; doi: 10.1111/tesg.12385

\begin{abstract}
This paper reflects critically on city branding by building on Kavaratzis and Ashworth's 2005 article 'City branding: An effective assertion of identity or a transitory marketing trick?' It discusses the relationships between urban geography and branding studies, and challenges the idea that cities may be considered as special kinds of products in need of specific branding techniques. This exercise entails reflection on the boundaries between the concept of branding and its potential relation with the commodification of cities.
\end{abstract}

\section{Keywords}

City branding; place branding; product branding; marketing; critical urban geography 


\section{Introduction}

In this paper I will consider commodification, the politics of branding, and the relations between critical urban scholarship and marketing studies in light of Kavaratzis and Ashworth's paper 'City Branding: An Effective Assertion of Identity or a Transitory Marketing Trick?', published in this Journal in 2005. Specifically, I will reflect on certain key ideas, such as the political and relational nature of urban brands, in order to approach - and hopefully challenge, as other authors have done before me (for example Boland 2013) - one of the arguments proposed by Kavaratzis and Ashworth: the idea that cities may be considered special kinds of products in need of specific branding techniques. I will stress the political nature of this theoretical construct: at first sight, the idea that, in some way, cities may be viewed as 'products' seem to be coherent with those neoliberal approaches which consider urban space to be an asset which can be packaged, advertised and 'sold' in a global marketplace in order to extract economic value, which in essence is the idea of turning cities into commodities. This tendency towards the global commodification of the urban has been challenged by scholars in critical urban studies produced in recent decades (see for example Leitner et al. 2007) and, as I will argue, this may partly explain the difficulty of locating the concept of city branding in critical urban debates (although Kavaratzis and Ashworth's works are undoubtedly 'critical' from many points of view), ultimately determining its relative marginalisation in research agendas and underdevelopment in theoretical terms. In line with of the arguments of authors such as Brenner (2009) and Roy (2016), critical urban studies are understood here as sets of theories and analyses involving both a critique of existing social relations, for example in terms of power, ideology, inequality, injustice and exploitation within and among cities, and the search for emancipatory alternatives. Branding, in this framework, has been much criticised, as discussed in the next sections.

In order to develop the argument, I will start with autobiographical remarks about my encounter with the paper in order to describe the impact of Kavaratzis and Ashworth's work on debates of the early 2000s. I will then critically comment on the main ideas at the basis of their article, in order to move to the final part of this paper, in which I reflect on the boundaries and ideologies of city branding, and on the relationships between critical urban studies and branding studies.

\section{How I met 'city branding', or locating Kavaratzis and Ashworth in urban geography}

Over the years, geographers - as well as other scholars engaged with critical urban studies have contributed to debates on branding: I can mention for example the 2003 symposium on branding in the International Journal of Urban and Regional Research (Hannigan 2003), and an influential paper on the geographies of brands and branding (Pike 2009) published in 2009 by Progress in Human Geography. However, during my (almost) 20 years of career in the field of urban geography, I have encountered a relatively limited number of books, papers, workshops, conference sessions and research projects explicitly addressing the concept of place (or city) branding. My impression is that, within the community of critical urban geographers, the topic has often been approached with a certain degree of complacency and moralism: place branding has often been considered to be stuff for practitioners and business studies, and little 
more than the practice of selling cities. David Harvey, for example, in many influential works has described branding as the 'big business' of raising symbolic capital in order to mark distinction and to obtain a monopoly position with the aim of selling a piece of history (see for example Harvey, 1989 and, more recently 2012). To be noted is that the metaphor of 'selling' the city has been explicitly mobilised in several significant works on place branding published over the years, such as those by Ashworth and Voogd (1990), Kearns and Philo (1993), Short and Kim (1998), Ward (1998), Mele (2000),

Broudehoux (2004), Greenberg (2008), Aytar and Rath (2012) and Oh (2018). Branding is hence often conceived as the ultimate threshold in reducing urban life to a commodity, that is, transforming the complexity of urban spaces, their lives, their histories and their atmospheres into assets and experiences to be acquired and consumed.

The difficult relation between critical urban studies and marketing studies has probably also had to do with differences in the mechanisms of circulation of knowledge: put simply, branding is not a discipline but a topic, and scholars tend to belong to distinct academic communities engaging with distinct debates, conferences and academic journals. As a form of exercise, I have looked at the affiliations of the 202 scholars who authored and co-authored papers included in the proceedings of the Inaugural Conference of the International Place Branding Association, which took place in London, December 2016. Only five authors worked in geography departments, and only six in planning departments. ${ }^{1}$ This means that the vast majority of the authors worked in academic departments related to business studies, marketing, tourism and communication, among others. Cross-fertilisation between geography and branding studies has been hard to achieve, but, as I will argue in this paper, it took form particularly thanks to works such as that by Kavaratzis and Ashworth (2005).

My personal encounter with city branding dates back to about 2003, when I became fascinated with the topic of urban images and city representations. But the word itself 'image' proved to be rather slippery, and at the beginning I confusedly started to read very different and disconnected works ranging from Kevin Lynch's (1960) milestone book on the image of the city, to Gillian Rose's (2001) speculation on the visual, to Hannigan's (1998) work on fantasy cities, to Rob Shield's (1991) wonderful book Places on the Margins. I also started to attend academic conferences on the topic. Particularly, during a session in Glasgow, about 2004, I remember a speaker predicting that city branding would gain huge popularity in urban studies. In his colloquial words, 'everybody is going to study and write about city branding in the next years'. I was quite impressed by those words, which were not really prophetic. For me, branding was just another glittering term for marketing. Still, in those years, debates on place branding gained a certain momentum, and I became involved in the activities of colleagues in the field, although I generally referred to the more general (and supposedly critical) expression 'politics of representation', rather than simply 'branding'. The literature, at that time, was rather imprecise in its terminology, and not at all clear was the difference between terms like city 'branding' and 'marketing' (as recently discussed by Boisen et al. 2018 and by Kavaratzis 2018, among others), where, in extreme synthesis, the former refers to practices of advertising and promoting a city, while the latter is supposed to concern deeper processes of placemaking and collective identity formation. Moreover, to be noted is that key scholars in urban

\footnotetext{
${ }^{1}$ I have simply checked the names of departments containing the keywords 'geography', 'urban', 'city' and 'planning'. Of course, this is a merely indicative exercise with evident limitations.
} 
studies had developed influential ideas about the shaping of market-oriented urban images, without even using terms such as 'marketing' or 'branding'. This is, for example, the case of the influential work of David Harvey (1989, pp. 7-8), who discussed the socio-political problems and inequalities connected to 'the up-grading of the image of cities like Baltimore, Liverpool, Glasgow or Halifax', or the case of Neil Smith (1996), who analysed gentrification in relation to urban commodification, urban imaginaries and collective identities without using either the keyword 'marketing' or 'branding'. Apparently, urban geographers did not need to use expressions coming from the world of business studies in order to analyse and discuss the problems connected to image building, image promotion and the commodification of the urban. And I was critical about the practice of mobilising 'flat' business concepts (marketing, benchmarking, ranking, etc.) in critical urban geography by simply adding adjectives such as 'urban', 'regional' or 'spatial'.

However, in my experience, Italian policy-makers were greatly attracted by those terms and ideas. This was clear in my hometown, which is Turin: the first strategic plan of the city, published in 2000, mobilised the word 'marketing' in its 120 pages only a couple of times, while in the second edition, published in 2006, the term was repeated dozens of times. In that period, my academic position was precarious, and I worked on research studies commissioned by local governments, in Turin and in other Italian cities. Local policy-makers were investing considerable resources, including European money from structural funds, in order to develop benchmarking analysis on city competitiveness, marketing and ranking. I developed some experience in the field, but with a sense of frustration. The kind of knowledge and studies that local governments were searching for were very distant from the kind of knowledge and studies that were supposed to be produced by a critical geographer. They were asking for city rankings, ordering cities from the 'best' to the 'worst' according to parameters related to their supposed attractiveness, in order to detect potential assets with the ultimate goal of developing strategies for moving up the charts. Ultimately, I was contributing to the production of very normative, straightforward and market-oriented understandings of the urban. To put it differently, I had become an agent of urban entrepreneurialism (cf. Hall \& Hubbard 1996). It is easy for me to understand why many critical geographers had developed a certain hostility towards the concepts and practices of 'branding' places.

This is the framework in which I encountered Kavaratzis and Ashworth's 2005 paper, a piece of work that quickly became a standard reference for me and for many other scholars. Ashworth has an academic background and a PhD in Geography, and the two authors were working at the intersection among urban, tourism and marketing studies, proving that it was possible to develop meaningful reflections across those fields. The title of the article was precise, and even the headings of the various sections were clear and promising: 'From place marketing to place branding' (p. 506); 'What is place branding?' (p. 508); 'From products to places' (p. 510). That paper was going to answer my doubts and questions. And it was published in a serious geographic journal, stimulating the debate in my specific academic field. 


\section{City branding and product branding}

Clearly, one of the main problems in transferring concepts like marketing, branding or advertising to geographical entities has to do with the fact that, for many critical scholars, space is a fictitious commodity (as well as labour and capital as famously discussed by Polanyi 1944, who however wrote about 'land', and not 'space'). Space may be intended as fictitious because it cannot be produced in order to be bought and sold, and because the mere fact of possessing a body implies occupying a space, so that space cannot be fully separated from life itself. Well-known Marxist speculations on the production of space, the right to the city and the distinction between use and exchange values have deep roots connected to this perspective (see for example the many works inspired by the ideas of Henri Lefebvre 1968).

Terms like 'commodity' and 'product' are not the same in economic terms; however, in social science, a commodity is generally conceived as 'any thing intended for exchange' (Appadurai 2005 , p. 35). Commodification may be simply understood as the process of making things tradeable in the market. Under advanced capitalism, commodification expands into every aspect of social and political life, exposing human life to a global marketisation of everything (Gilbert 2008). The logics of commodity fetishism, as described by Karl Marx, have been extended into unexpected areas of social life, including urban life and urban experiences. The more commodification spreads, the more it is naturalised, ultimately reducing the possibility to set limits on its expansion (Leys 2001). Hegemonic narratives on global urban competitiveness, on cities as engines of growth in global networks, or those about the hierarchical structure of world urbanisation (with alpha, beta and gamma cities) are often taken for granted in urban studies, arguably contributing to the naturalisation of the commodification of cities, at least on a conceptual level.

The first generation of works on city marketing were quite straightforward from this point of view. They assumed - explicitly or implicitly - that places are products, and hence objects which may be defined by their exchange value and which have to be positioned in the market. Consider, for example, the very influential book Marketing Places by Kotler et al. (1993), which has thousands of citations on Google Scholar. In the first lines of the book, the authors affirm that 'places are more than budgets and business. They are people, cultures, historical heritage, physical assets, and opportunities' (p. 2). However, after some pages, a straightforward assumption is presented: 'every community has to transform itself into a seller of goods and services, a proactive marketer of its products and its place value. Places are, indeed, products, whose identities and values must be designed and marketed' (p. 10). Of course, also the literature targeting practitioners is clear about the fact that places cannot be promoted, advertised, communicated, marketed or branded in the same way as ordinary commodities (see for example the influential works of Ashworth \& Voogd 1990, and Gold \& Ward 1994). Nevertheless, most analyses and speculations build on the implicit idea that places are kinds of 'special' products that need to be marketed and sold with dedicated techniques in order to extract value, in a scenario of global competition among cities in order to attract global flows (investments, events, tourists, enterprises - which are basically other names for money).

Kavaratzis and Ashworth were lucid in analysing this phenomenon. According to them, marketing specialists 'too easily assume that places are just spatially extended products that require little special attention as a consequence of their spatiality' (p. 507). In order to overcome this limit, and to develop a more robust understanding of spatial objects, they 
mobilised concepts from cultural geography, and particularly the rich geographical literature on the sense of place in order to develop a relational understanding of space and place brands. This may sound unsurprising for a geographer, but it has been an important step in order to build a bridge between different styles of scholarship. Particularly, the article deals with the difficult exercise of linking geographical literature to key conceptualisations from corporate branding, most of all by insisting on the idea that brands are relational constructions, namely, the outcomes of two-way processes involving producers and consumers. In this sense, it is clear that branding is more than developing a catchy slogan with a punchy logo. Nevertheless, the migration of this idea into the sphere of spatial entities is problematic. Some authors argue that place branding is 'impossible' if one considers that 'places are not products, governments are not producers, and users are not consumers' (Hankinson 2001, quoted in Kavaratzis and Ashworth 2005,

p. 510). However, the main thesis of 'City Branding: An Effective Assertion of Identity or a Transitory Marketing Trick?' is that it is possible to brand places in a conceptually coherent way: 'we can accept places as brandable products if their intrinsic and distinctive characteristics as place products are understood and a special form of marketing developed' (p. 510).

This position may be controversial for critical urban scholars because it still supports and reproduces the idea that places are products of some kind, ultimately contributing to the conceptual commodification of cities and urban experiences. It should be acknowledged, however, that Kavaratzis and Ashworth mobilised concepts from corporate branding with close attention and sensitivity to space, exploring the geographical nature of branding practices and the conceptual differences between marketing and branding. Different understandings of spatial branding are classified (such as co-branding and place management), and an optimistic view of the possibilities for branding is ultimately proposed. The authors recognise the multiplicity of positionalities characterising urban experiences: the city may be for example a place of residence, work, emancipation, opportunity, resistance, negotiation of difference, struggle and hope in the eyes of different subjects. While the marketing literature suggests targeting and differentiation, selling different 'layers' or 'slices' of the urban experience to different audiences, Kavaratzis and Ashworth (2005) recommend a more systematic approach by considering the city as an organic whole, and stressing the need to develop credible stories from within (storytelling wasn't yet a popular buzzword). Debates on creative cities were gaining popularity in those years (Landry 2000; Florida 2002), and the article's conclusions are coherent with those debates. It is worth mentioning that critical geographers in that period were readily stressing the political nature of discourses on creative and cultural cities, and related urban imaginaries (see for example Peck 2005). 


\section{Critical urban geographies: producing, consuming and prosuming brands}

Marketing and branding are certainly political objects because they are clearly bound up with issues of conflict, inequality, visibility and invisibility, identity formation, framing, inclusion and exclusion, as stressed many years ago by scholars such as Madsen (1992), Paddison (1993), Zukin (1995) or Hall and Hubbard (1996), and fully recognised by Kavaratzis and Ashworth, too. In the same year as the publication of 'City Branding: An Effective Assertion of Identity or a Transitory Marketing Trick?', a very influential article by Adam Arvidsson (2005) proposed a Marxist approach to the analysis of retail brands which inspired many geographers - including myself - by arguing that branding techniques allow the extraction of surplus value and the exploitation of the free labour of the consumers. More recent in the literature on branding is the attempt to challenge the straightforward assumption that branding is a hegemonic force reproducing capitalistic logics of exploitation and commodification. This work has been done for example by Andrea Lucarelli (2018). Mobilising the ideas of critical political philosophers such as Giorgio Agamben, Roberto Esposito and Jacques Ranciére, Lucarelli proposes at the notion of city branding as a 'processual hybrid policy' in which 'the public and the private, economics and politics, and the market and the polis are blurred and co-emerge (i.e. as a process) in a relational and interactive manner' (p. 12). Ultimately, Lucarelli argues that branding may produce positive outcomes in the political sphere, such as enabling new and progressive ways to frame political subjects and urban phenomena. This is coherent with the positions of those scholars who have analysed counter-branding practices: Maiello and Pasquinelli (2015), for example, considered counter-hegemonic representational practices enacted in order to oppose the official branding of Rio de Janeiro on the occasion of the 2014 FIFA World Cup and the 2016 Olympic Games, and Lucarelli himself presented the case of a counter-campaign which came about in Stockholm. Bookman (2017) explored the complex relationship among brands, consumption and urban life, focusing on how brands mediate identities, lifestyles and social relations. According to Bookman, brands enact socio-spatial division and exclusion in the city by defining what kinds of practices, images or attitudes are acceptable in a particular place, constituting cultural boundaries that keep certain people and activities out. Accordingly, counter-branding practices may be conceived as claims for the right to the city (Masuda \& Bookman 2018).

I think that the problem of setting the boundaries of what we conceive as 'branding' is crucial for critical scholarship. Is it conceptually useful to consider branding as a 'thing' which includes the forces, discourses and practices actually opposing what is generally understood as branding? In other words: is branding the mere activity of city managers and/or specialised agencies seeking urban boosterism in a framework clearly connected to the ideologies of neoliberalism and urban entrepreneurialism, or is branding instead a perspective from which to study urban phenomena, since also ordinary, marginal, provincial and minoritarian subjects produce discourses and practices that ultimately shape place brands and urban images? Consider, as an analogy, the case of conceptual approaches to tourism studies. A large part of this field of studies focuses on the management of the phenomenon (as in the case of tourist destination management studies). But over the years a critical scholarship has evidenced that studying tourism is a way to reflect on society, modernity and everyday life (see for example Minca \& Oakes 2014). However, in the case of place branding, critical approaches are still relatively rare in human geography. This is not to say that geographers and critical urban studies have not meaningfully contributed to the literature on city branding. On the one hand, 
a large number of classic critical works, like those by David Harvey and Sharon Zukin, have enhanced understanding of the politics of image building and interurban competition. On the other hand, scholars have developed a large body of meaningful situated analysis challenging the idea that branding is a homogeneous phenomenon comprising similar messages, similar strategies and similar rationalities all over the world. The analysis of the 'selling' of post-Mao Beijing conducted by Broudehoux (2004), the 'staging' of the 'new' Berlin by Colomb (2011), the branding of Buenos Aires by Dinardi (2017) and that of Johannesburg by Sihlongonyane (2015), present very different case studies illuminating about the actual existing practices and phenomena related to city branding. Still, in my view, two elements have limited the diffusion of critical analysis explicitly addressing branding in human geography.

First, I maintain that assuming branding as an analytical perspective in geography is troublesome because there are already other concepts in the discipline which have a solid background and which may serve the same purpose. If we assume a wide understanding of place brands, one that emphasises the plurality of voices, imaginaries, positionalities and stories characterising a city, it becomes very difficult to distinguish among urban brands, urban images and place-making. This is because we are basically talking about place, and it is no coincidence that Kavaratzis and Ashworth referred exactly to that literature.

Second, it is hard to develop any understanding of branding without mobilising the equation places $=$ products, an idea which may be disturbing for most critical geographers. Kavaratzis and Ashworth concluded their paper by specifically proposing that places are 'distinctive products' and that place branding is a distinctive form of branding. The logical construction of the argument is solid: places are distinctive because, for example, it is often impossible to distinguish between brand producers and consumers, and hence brands are prosumed by inhabitants and city users (cf. Zenker \& Erfgen 2014). However, as a critical geographer, I wanted to challenge the very core of this argument. I tried to write about branding, without discursively performing the conceptual commodification of cities. With this perspective in mind, I speculated on branding as a ghostly politics of representation which originates three layers of visibility: first, branding clearly emphasises specific discourses, places, subjects and narrations; secondly, it implicitly marginalises and makes invisible (or irrelevant) other subjects, spaces and issues disturbing the promotional narrative; at the same time (third) it generates disturbing 'ghosts' - intended as liminal objects, memories, subjects and atmosphere standing in-between the visible and the invisible, the past and present, the individual and the collective - which troubles urban branding (Vanolo 2017).

Kavaratzis and Ashworth's paper has undoubtedly had a strong influence on geographical debates. Most of the ideas presented in the paper are still valid and topical, despite the fact that branding techniques have changed greatly in the past decade, mostly because of the massive spread of new forms of digital communication and social network technologies, potentially transforming any tourist, reviewer and blogger into an influencer in branding places. There are currently wider and stronger possibilities for counter-branding and for the proliferation of counter-narratives challenging monolithic representations of places (Vanolo 2017). Nevertheless, there is a need for further theoretical developments and analysis in critical geography: for example, by exploring how people cohabit with brands, how brands are experienced and embodied, how they contribute in producing subjects and discourses, and how place brands may be tools for collective resistance, supporting the quest for what Massey 
(1994) called 'a global sense of place', one that is progressive, not self-closing and defensive, but outward-looking. Put differently, it is necessary to study how brands contribute to the production of space beyond the plain assumption that they act as agents of commodification, homogenisation and neoliberalism. In fact, thanks to Kavartzis and Ashworth, we now have clearer ideas about the mobilisation of perspectives and approaches from product branding to place branding, but still it is difficult to frame, understand and subvert market-oriented approaches to place branding and the politics of commodification of cities.

\section{References}

Appadurai, A. (2005), Commodities and the Politics of Value. In: M. Ertman \& J. C. Williams, eds., Rethinking Commodification: Cases and Readings in Law and Culture, pp. 34-43. New York: New York University Press.

Arvidsson, A. (2005), Brands: A Critical Perspective. Journal of Consumer Culture 5, pp. 235-258.

Ashworth, G. J. \& H. Voogd (1990), Selling the City: Marketing Approaches in Public sector urban planning. Oxford: Belhaven.

Aytar, V. \& J. Rath, eds. (2012), Selling Ethnic Neighborhoods: The Rise of Neighborhoods as Places of Leisure and Consumption. New York: Routledge.

Boisen, M., K. Terlouw, P. Groote, \& O. Cowenberg. (2018), Reframing Place Promotion, Place Marketing, and Place Branding - Moving beyond Conceptual Confusion. Cities 80, pp. 411.

Boland, P. (2013), Sexing up the City in the International Beauty Contest: The Performative Nature of Spatial Planning and the Fictive Spectacle of Place Branding. Town Planning Review 84, pp. 251-274.

Bookman, S. (2017), Brands and the City: Entanglements and Implications for Urban Life. New York: Routledge.

Brenner, N. (2009), What is Critical Urban Theory? City 13, pp. 198-207.

Broudehoux, A.-M. (2004), The Making and Selling of Post-Mao Beijing. London: Routledge.

Colomb, C. (2011), Staging the New Berlin. Place Marketing and the Politics of Urban Reinvention Post-1989. London: Routledge.

Dinardi, C. (2017), Cities for Sale: Contesting City Branding and Cultural Policies in Buenos Aires. Urban Studies 54, pp. 85-101.

Florida, R. (2002), The Rise of the Creative Cass. And How it's Transforming Work, Leisure, Community, and Everyday Life. New York: Basic Books.

Gilbert, J. (2008), Against the Commodification of Everything. Cultural Studies 22, pp. 551-566.

Gold, J.R. \& S.V. Ward, eds. (1994), Place Promotion: The Use of Publicity and Marketing to Sell Towns and Regions. Chichester: John Wiley \& Sons.

Greenberg, M. (2008), Branding New York: How a City in Crisis was Sold to the World. London: Routledge.

Hall, T. \& P. Hubbard (1996), The Entrepreneurial City: New Urban Politics, New Urban Geographies? Progress in Human Geography 20, 153-174.

Hankinson, G. (2001), Location Branding: A Study of the Branding Practices of 12 English Cities. Journal of Brand Management 9, pp. 127-142.

Hannigan, J. (1998), Fantasy City: Pleasure and Profit in the Postmodern Metropolis. New York: Routledge.

Hannigan, J. (2003), Symposium on Branding, the Entertainment Economy and Urban Place Building: Introduction. International Journal of Urban and Regional Research 27, pp. 352360 . 
Harvey, D. (1989), From Managerialism to Entrepreneurialism: The Transformation in Urban Governance in Late Capitalism. Geografiska Annaler B 71, pp. 3-17.

Harvey, D. (2012), Rebel Cities: From the Right to the City to the Urban Revolution. London: Verso.

Kavaratzis, M. (2018), Place Branding: Are We Any Wiser? Cities 80, pp. 61-31.

Kavaratzis, M. \& G.J. Ashworth (2005), City Branding: An Effective Assertion of Identity or a Transitory Marketing Trick? Tijdschrift voor Economische en Sociale Geografie 96, pp. 506-514.

Kearns, G. \& C. Philo, eds. (1993), Selling Places. The City as Cultural Capital, Past and Future. Oxford: Pergamon Press.

Kotler, N., J. Haider \& L. Miller (1993), Marketing Places. Attracting Investments, Industries, and Tourism to Cities, States, and Nations. New York: The Free Press.

Landry, C. (2000), The Creative City. A Toolkit for Urban Innovators. London: Earthscan.

Lefebvre, H. (1968), Le droit à la ville. Paris: Anthropos.

Leitner, H., J. Peck \& E. Sheppard, eds. (2007), Contesting Neoliberalism. Urban Frontiers. London: The Guilford Press.

Leys, C. (2001), Market Driven Politics. London: Verso.

Lucarelli, A. (2018), Place Branding as Urban Policy: The (Im)political Place Branding. Cities 80, pp. 12-21.

Lynch, K. (1960), The Image of the City. Cambridge, MA: MIT Press.

Madsen, H. (1992), Place-marketing in Liverpool: A Review. International Journal of Urban and Regional Research 16, pp. 633-640.

Maiello, A. \& C. Pasquinelli (2015), Destruction or Construction? A (Counter) Branding Analysis of Sport Mega-events in Rio de Janeiro. Cities 48, pp. 116-124.

Massey, D. (1994), Space, place, and Gender. Minneapolis, MN: University of Minnesota Press.

Masuda, J.R. \& S. Bookman (2018), Neighbourhood Branding and the Right to the City. Progress in Human Geography 42, pp. 165-182.

Mele, C. (2000), Selling the Lower East Side: Culture, Real Estate, and Resistance in New York City. Minneapolis, MN: Minnesota University Press.

Minca C. \& T. Oakes (2014), Tourism after the Postmodern Turn. In: A. Lew, M. Hall \& A. Williams, eds., The Wiley Blackwell Companion to Tourism, pp. 294-303. Hoboken, NJ: Wiley.

Oh, J. (2018), Pop City: Korean Popular Culture and the Selling of Place. Ithaca, NY: Cornell University Press.

Paddison, R. (1993), City Marketing, Image Reconstruction and Urban Regeneration. Urban Studies 30, pp. 339-350.

Peck, J. (2005), Struggling with the Creative Class. International Journal of Urban and Regional Research 29, pp. 740-770.

Pike, A. (2009), Geographies of Brands and Branding. Progress in Human Geography 33, pp. 619645.

Polanyi, K. (1944), The Great Transformation. New York: Farrar \& Rinehart.

Rose, G. (2001), Visual Methodologies. London: Sage. Roy, A. (2016), What is Urban about Critical Urban Theory? Urban Geography 37, pp. 810-823.

Shields, R. (1991), Places on the Margin. Alternative Geographies of Modernity. London: Routledge.

Short, J.R. \& Y.-H. Kim (1998), Urban Crisis/Urban Representations: Selling the City in Difficult Times. In: T. Hall \& P. Hubbard, eds., The Entrepreneurial City. Geographies of Politics, Regime and Representation, pp. 55-75. Chichester: John Wiley \& Sons.

Sihlongonyane, M.F. (2015), The Rhetorical Devices for Marketing and Branding Johannesburg as a City: A Critical Review. Environment \& Planning A 47, pp. 2134-2152. 
Smith, N. (1996), The New Urban Frontier: Gentrification and the Revanchist City. New York: Routledge.

Vanolo, A. (2017), City Branding. The Ghostly Politics of Representation in Globalising Cities. New York: Routledge.

Ward, S.V. (1998), Selling Places: The Marketing and Promotion of Towns and Cities 1850-2000. London: Routledge.

Zenker, S. \& S. Erfgen (2014), Let Them Do the Work: A Participatory Place Branding Approach. Journal of Place Management and Development 7, pp. 225-234.

Zukin, S. (1995), The Cultures of Cities. Oxford: Blackwell. 